\title{
Nerve growth potential of FK 506 and its analogues - A systematic review of controlled trials in rats
}

\author{
Pramod K Nelluri MD ${ }^{1}$, Robert Lyons MD ${ }^{1}$, Antonio Severo MD², Darryl W Peterson MD ${ }^{3}$, \\ Uli K Chettipally MD MPH${ }^{4}$, Jamie R Garza DDS MD ${ }^{1}$ \\ ${ }^{I}$ Division of Plastic \& Reconstructive Surgery, University of Texas Health Science Center, San Antonio, \\ Texas, ${ }^{2}$ Christine M Kleinert Institute for Hand \& Microsurgery, Louisville, Kentucky, ${ }^{3}$ Louisiana \\ Orthopedic Institute, Baton Rouge, Louisiana, ${ }^{4}$ Chief of Department of Emergency Medicine, Kaiser \\ Permanente Medical Center, South Francisco, California, USA
}

PK Nelluri, R Lyons, A Severo, DW Peterson, UK Chettipally, JR Garza. Nerve growth potential of FK 506 and its analogues A systematic review of controlled trials in rats. Can J Plast Surg 2000;8(3):97-100.

BACKGROUND: Nerve injuries of the upper extremity seldom regain full preinjury function. Delay in nerve repair, nerve gap and ischemic local conditions are some of the factors attributed as the cause. The proximal axonal segment regenerates in the presence of neuronotrophic factors present in nerve tissue. FK 506 and its nonimmunosuppressive analogues have been shown to influence the growth of axons experimentally. Parallel studies of animals and human beings have demonstrated strong, toxic effects of these agents.

PURPOSE: To review systematically data on the role of FK 506 and its analogues in peripheral nerve regeneration of randomized, controlled trials in rats. Reports dealing with the toxic effects of these agents all were reviewed as well.

METHODS: Articles and reviews were identified through a computerized search of MEDLINE from January 1966 to September 1999 by using the terms "FK 506", "FKBP-12 ligands", "peripheral nerve regeneration" and "nephrotoxicity, cardiotoxicity and neurotoxicity in FK 506". Two reviewers assessed the trials independently.

RESULTS: FK 506 caused dose-related enhancement of axonal growth in all animals that were tested and for all routes of drug administration. Effects of FK 506 when used locally and of its analogues occurred in the same order as those of the parent drug. CONCLUSIONS: FK 506 and its analogues have been experimentally proven to be potent nerve stimulators. Further studies are warranted in view of the pathological and clinical potential for nephrotoxicity and cardiotoxicity of these agents. The authors proposed an experimental model incorporating a nerve conduit filled with slow release FK 506 at the site of nerve gap or crush, thus decreasing its systemic effects.

Key Words: FK 506; FK 506 ligands; Immunophillin ligands; Nephrotoxicity; Peripheral nerve regeneration

Potentiel de repousse des nerfs induite par le FK 506 et de ses analogues - une revue systématique des essais comparatifs menés sur des rats

CONTEXTE : Les lésions nerveuses des membres supérieurs récupèrent rarement l'intégralité de leur fonction après une blessure. Parmi les facteurs imputables à cette perte fonctionnelle figurent une réparation tardive des nerfs, une section des nerfs ou des conditions locales d'ischémie. Le segment axonal proximal se régénère sous l'influence de facteurs neuronotrophiques présents dans le tissu nerveux. Il a été démontré expérimentalement que le FK 506 et ses analogues non immunosuppresseurs influençaient la repousse des axones. Cependant, des études parallèles menées sur des animaux et des êtres humains ont démontré que ces agents avaient d'énormes effets toxiques. BUT : Procéder à un examen systématique des données sur le rôle du FK 506 et de ses analogues dans la régénération des nerfs périphériques dans des essais comparatifs et randomisés menés sur des rats. Tous les rapports faisant état des effets toxiques de ces agents ont également été passés en revue.

voir page suivante

Correspondence and reprints: Dr Pramod K Nelluri, Division of Plastic \& Reconstructive Surgery, University of Health Science Center, San Antonio, Mail Code 7844, 7703 Floyd Curl Drive, San Antonio, Texas - 78229-3900, USA. Telephone 210-567-5760, fax 210-567- 6390, e-mail p_nelluri@hotmail.com 
MÉTHODES : On a recherché au moyen de la base de données informatisée Medline les articles et les synthèses publiées de 1966 janvier de septembre 1999 au moyen des termes «FK 506 », « FKBP-12 ligands », «peripheral nerve regeneration », "nephrotoxicity, cardiotoxicity and neurotoxicity in FK 506 ». Les études ont été évaluées par deux réviseurs indépendants.

RÉSULTATS : Le FK 506 a entraîné une stimulation de la croissance axonale proportionnelle à la dose administrée chez tous les animaux testés et pour toutes les voies d'administration. Les effets du FK 506 quand ce dernier était administré localement et ceux de ses analogues sont survenus dans la même proportion que ceux du médicament apparenté.

CONCLUSIONS : Il a été expérimentalement démontré que le FK 506 et ses analogues étaient de puissants stimulateurs nerveux. D’autres études sont justifiées vu le potentiel clinique et pathologique de cardiotoxicité et de néphrotoxicité de ces agents. Les auteurs ont suggéré un modèle expérimental incorporant un conduit nerveux rempli de FK 506 à libération prolongée à l'endroit de la section ou de l'écrasement du nerf, ce qui permettrait ainsi de diminuer ses effets généraux.

$\mathrm{P}$ eripheral nerve damage, such as that caused by trauma, cannot always be repaired primarily and often requires nerve grafting. Patients suffering from these injuries are often devastated and rarely return to preinjury employment or avocations $(1,2)$. Treatments that enhance the rate and/or degree of axonal recovery across a peripheral nerve injury and/or gap and yield superior clinical outcomes result in less patient suffering and disability, and fewer lost days of work (3). FK 506, widely used as an immunosuppressant, has been shown to enhance axonal regeneration in experimental animals (4). However, the drug, which has mostly replaced cyclosporin $\mathrm{A}$ as an immunosuppressant, has been found to be no less toxic, both in humans and animals $(5,6)$. Recent experiments with nonimmunosuppressant analogues of FK 506 have shown equal potency in enhancing axonal regeneration $(7,8)$. Studies using the rat sciatic nerve model have demonstrated statistically significant growth in the density of axonal fibres and faster rate of regeneration in the drug-treated animals compared with those of controls. The present study used a systematic review of the literature to analyze and compare FK 506 and its analogues in their role as neuronotrophic agents.

\section{STUDY SELECTION}

By reviewing the literature on FK 506 and its analogues, 10 articles and reviews were identified through a computerized search of the National Library of Medicine's MEDLINE database from January1966 to September 1999. English-based literature using the search words "FK 506", "peripheral nerve regeneration" and "FKBP-12 ligands" combined with "neurotoxicity", "cardiotoxicity" and "nephrotoxicity" of FK 506 was compiled. A total of 17 articles on FK 506, its analogues and its toxicities are cited in this review.

\section{RESULTS}

Six studies used FK 506 and four used one of its analogues as the agent (Table 1). Eight studies used the sciatic nerve crush model. Fansa et al (9) used the same nerve segment orthotopically, and Doolabh et al (10) used a nerve graft from the posterior tibial nerve. The doses varied among the studies and so did the routes of drug administration. In terms of morphometric measures such as axonal calibres (AC), mean axonal areas (MAA) and axonal density (AD), a more than $50 \%$ increase in experimental animals compared with controls was observed. Functional recovery measured by walking
TABLE 1

Summary of trials

\begin{tabular}{|c|c|c|c|c|c|}
\hline $\begin{array}{l}\text { Author, } \\
\text { (reference) }\end{array}$ & Model & Drug & Dose (mg/kg) & Route & $\mathbf{n}$ \\
\hline Gold et al (4) & $\begin{array}{l}\text { Sciatic nerve } \\
\text { crush }\end{array}$ & FK 506 & 1.0 & Subcutaneous & 5 \\
\hline Gold et al (4) & $\begin{array}{l}\text { Sciatic nerve } \\
\text { crush }\end{array}$ & FK 506 & 1.0 & Subcutaneous & $v$ \\
\hline $\begin{array}{l}\text { Wang et al } \\
\text { (18) }\end{array}$ & $\begin{array}{l}\text { Sciatic nerve } \\
\text { crush }\end{array}$ & FK 506 & $2.0,5.0,10.0$ & Subcutaneous & $3 / 5^{*}$ \\
\hline $\begin{array}{l}\text { Steiner } \\
\text { et al (7) }\end{array}$ & $\begin{array}{l}\text { Sciatic nerve } \\
\text { crush }\end{array}$ & FK 506 & 1.0 & Local & 5 \\
\hline $\begin{array}{l}\text { Steiner } \\
\text { et al (7) }\end{array}$ & $\begin{array}{l}\text { Sciatic nerve } \\
\text { crush }\end{array}$ & L-685,818 & 1.0 & Local & 5 \\
\hline Gold et al (4) & $\begin{array}{l}\text { Sciatic nerve } \\
\text { crush }\end{array}$ & $V-10,367$ & 200.0 & Subcutaneous & 3 \\
\hline Gold et al (4) & $\begin{array}{l}\text { Sciatic nerve } \\
\text { crush }\end{array}$ & V-10,367 & $5.0,15.0,50.0$ & Oral & $v$ \\
\hline $\begin{array}{l}\text { Steiner } \\
\text { et al (7) }\end{array}$ & $\begin{array}{l}\text { Sciatic nerve } \\
\text { crush }\end{array}$ & GPI-1046 & $3.0,10.0$ & Subcutaneous & 6 \\
\hline Fansa et al (9) & Autograft & FK 506 & $0.3,0.6$ & Subcutaneous & 8 \\
\hline $\begin{array}{l}\text { Doolabh } \\
\text { et al (10) }\end{array}$ & $\begin{array}{l}\text { Post-tibial } \\
\text { nerve isograft }\end{array}$ & FK 506 & 1.0 & Intraperitoneal 1 & $15 / 10$ \\
\hline
\end{tabular}

*Control/experimental. $n$ Number of rats in each group; $v$ Variable number of rats in each group

track methods demonstrated significant earlier walking in the experimental animals.

\section{DISCUSSION}

A regenerating nerve is guided by the concepts of neurotropism and neurotrophism, which are inherent properties of peripheral nerve tissue. Numerous neuronotrophic factors such as nerve growth factor $(11,12)$, neurite-promoting factors including laminin (13) and fibronectin $(14,15)$, neural cell adhesion molecules and $\mathrm{N}$-cadherin (16), and numerous other hormonal factors have been identified at the site of axonal growth. FK 506, an agent fortuitously found to enhance axonal regeneration, has been shown to increase the $\mathrm{AC}$, axonal count, percentage of nerve fibres, rate of axonal advancement and myelin to axon ratio $(17,18)$. Similar experimental models using the nonimmunosuppressive ligands FK 506 analogues have shown equal nerve growth potential $(19,20)$. Further, these immunophillin ligands, which are devoid of calcineurin inhibitory activity, were shown to be effective orally (19). In addition, Steiner et al (7) used L-685,818, the Cl8-hydroxy, C21-ethyl derivative of FK 506, locally and 
showed an increase of about $75 \%$ in MAA in experimental rats compared with controls. In a comparative dose study, this agent did not show any toxicity in rats or in dogs (21). All four studies (Table 1) that used different analogues of FK 506 in their experiments demonstrated significant earlier functional recovery in experimental animals compared with controls.

Six studies (Table 1) used FK 506 and demonstrated significant improvement of MAA and $\mathrm{AD}$ of nerve fibres. Most of the studies used a dose of $1 \mathrm{mg} / \mathrm{kg}$ body weight subcutaneously or intraperitoneally. Fansa et al (9) used a dose of $0.6 \mathrm{mg} / \mathrm{kg}$ body weight and demonstrated a $75 \%$ increase in axonal count but did not observe a significant difference in the myelin to axon ratio between the two groups. In addition, both Fansa et al (9) and Doolabh et al (10) observed that the initial benefit seen at two and seven weeks was absent at six and 10 weeks, respectively. Therefore, the benefit of FK 506 seemed to be less effective after an initial period of regeneration. Wang et al (18) found that the ability of FK 506 to enhance axonal regeneration was dose dependent. Maximal acceleration was demonstrated in the group treated with $5 \mathrm{mg} / \mathrm{kg}$ body weight.

Only Fansa et al (9) addressed the side effects or toxic effects of the drug in their animals. Although initial studies suggested that FK 506 had limited nephrotoxicity, recent studies of animals and humans have indicated significant nephrotoxic potential $(22,23)$. For example, rats treated with $0.8 \mathrm{mg} / \mathrm{kg} / \mathrm{day}$, showed a $23 \%$ decrease in glomerular filtration rate at four weeks compared with that of controls (6). However, similar studies have demonstrated cardiotoxic and neurotoxic properties of the drug $(24,25)$. Therefore, to determine whether studies of drugs performed in animals are relevant to humans, a number of factors must be considered. These factors include drug dosage, route and schedule of

\section{REFERENCES}

1. Wong AY, Scott JJ. Functional recovery following direct or graft repair of nerve gaps in the rat. Exp Neurol 1991;114:364-6.

2. Novak CB, MacKinnon SE, Kelly L. Correlation of two-point discrimination and hand function following median nerve injury. Ann Plast Surg 1993;31:495-8.

3. Whitworth IH, Brown RA, Dore CJ, Anand P, Green CJ, Terenghi G. Nerve growth factor enhances nerve regeneration through fibronectin grafts. J Hand Surg [Br] 1996;21:514-22.

4. Gold BG, Dickerson TS, Austin DR, The immunosuppressant FK 506 increases functional recovery and nerve regeneration following peripheral nerve injury. Restor Neurol Neurosci 1994;6:287-96.

5. Shapiro R, Fung JJ, Jain AB, Parks P, Todo S, Strazl TE. The side effects of FK 506 in humans. Transplant Proc 1990;22:35-6.

6. Nielsen FT, Leyssac PP, Kemp E, Starklint H, Dieperink H. Nephrotoxicity of FK-506 in the rat. Studies on glomerular and tubular function, and on the relationship between efficacy and toxicity. Nephrol Dial Transplant 1995;10:334-40.

7. Steiner JP, Connolly MA, Valentine HL, et al. Neurotrophic actions of nonimmunosuppressive analogues of immunosuppressive drugs FK 506, rapamycin, and cyclosporin A. Nat Med 1997;3:421-8.

8. Gold BG, Zeleny-Pooley M, Wang MS, Chaturvedi P, Armistead DM. A nonimmunosuppressant FKBP-12 ligand increases nerve regeneration. Exp Neurol 1997;147:269-78.

9. Fansa H, Keilhoff G, Altmann S, Plogmeier K, Wolf G, Schneider W. The effect of the immunosuppressant FK 506 on peripheral nerve regeneration following nerve grafting. J Hand Surg [Br] 1999;24:38-42. drug administration, and comparability of drug metabolic pathways. In contrast to systemic administration of the drug, local application of the same dose seemed to be an attractive alternative, as shown by Steiner et al (7). In this trial, FK 506 was applied locally to the site of sciatic nerve crush in the dose of $1 \mathrm{mg} / \mathrm{kg}$ body weight. The observed results were a $63 \%$ increase in axonal diameter and a $75 \%$ increase in MAA.

In all studies, the animals were observed for a period of three weeks postoperatively, except for those in the study by Fansa et al (9) and those in the study by Doolabh et al (10). Whether the initial benefits, which were absent at a later time period in these two studies, are due to a pruning mechanism or a downregulation of axonal growth remains to be determined (9). Additional studies are needed to evaluate the relative merits and adverse effects of this drug in terms of peripheral nerve regeneration.

\section{SUMMARY}

Experimental studies in rats have determined that both FK 506 and its analogues enhanced nerve regeneration in terms of AC and number of fibres. In addition, they enhanced neurite outgrowth (26) and increased the rate of axonal advancement. However, when contemplating treatment with FK 506, given the numerous health risks associated with immunosuppression, whether the degree of enhancement outweighs the risks requires additional studies. Experiments with a nerve conduit filled with a slow release of the drug bridging the nerve gap or wrapped around the crush site are underway in our laboratory. Future studies concentrating on the analogues of FK 506 are warranted to explore further the potential benefits of these agents for the treatment of peripheral nerve injuries.

10. Doolabh VB, Mackinnon SE. FK 506 accelerates functional recovery following nerve grafting in a rat model. Plast Reconstr Surg 1999;103:1928-36.

11. Levi-Montalcini R. The nerve growth factor: thirty-five years later. EMBO J 1987;6:1145-54

12. Gundersen RW, Barrett JN. Characterization of the turning response of dorsal root neurites toward nerve growth factor. J Cell Biol 1980;87:546-54.

13. Lander AD. Molecules that make axons grow. Mol Neurobiol 1987;1:213-45.

14. Akers RM, Mosher DF, Lilien JE. Promotion of retinal neurite outgrowth by substratum-bound fibronectin. Dev Biol 1981;86:179-88.

15. Gundersen RW. Response of sensory neurites and growth cones to patterned substrata of laminin and fibronectin in vitro. Dev Biol 1987;121:423-31.

16. Dodd J, Jessell TM. Axon guidance and the patterning of neuronal projections in vertebrates. Science 1988;242:692-9.

17. Gold BG, Katoh K, Storm-Dickerson T. The immunosuppressant FK 506 increases the rate of axonal regeneration in rat sciatic nerve. J Neurosci 1995;15:7509-16.

18. Wang MS, Zeleny-Pooley M, Gold BG. Comparative dose-dependence study of FK 506 and cyclosporin A on the rate of axonal regeneration in the rat sciatic nerve. J Pharmacol Exp Ther 1997;282:1084-93.

19. Gold BG, Zeleny-Pooley M, Chaturvedi P, Wang MS. Oral administration of a nonimmunosuppressant FKBP-12 ligand speeds nerve regeneration. Neuroreport 1998;9:553-8.

20. Steiner JP, Hamilton GS, Ross DT, et al. Neurotrophic immunophillin 
ligands stimulate structural and functional recovery in neurodegenerative animal models. Proc Natl Acad Sci USA 1997;94:2019-24.

21. Dumont FJ, Staruch MJ, Koprak SL, et al. The immunosuppressive and toxic effects of FK-506 are mechanistically related: pharmacology of a novel antagonist of FK-506 and rapamycin. J Exp Med 1992;176:751-60.

22. A comparison of tacrolimus (FK 506) and cyclosporin for immunosuppression in liver transplantation. The US Multicenter FK 506 Liver Study Group. N Engl J Med 1994;331:1110-5.

23. Uchida J, Miura K, Yamanaka S, et al. Renal endothelin in
FK 506-induced nephrotoxicity in spontaneously hypertensive rats. Jpn J Pharmacol 1998;76:39-49.

24. Nomoto S, Fujiwara H, Ban T, Ohara K. Cardiotoxicity of long-term intravenous administration of FK 506 in rabbits: dose relationship and recovery after discontinuance. Transplant Proc 1994;26:855-7.

25. Mizisin AP, Powell HC. Toxic neuropathies. Curr Opin Neurol 1995;8:367-71.

26. Lyons WE, George EB, Dawson TM, Steiner JP, Snyder SH. Immunosuppressant FK 506 promotes neurite outgrowth in cultures of PC 12 cells and sensory ganglia. Proc Natl Acad Sci USA. 1994;91:3191-5. 